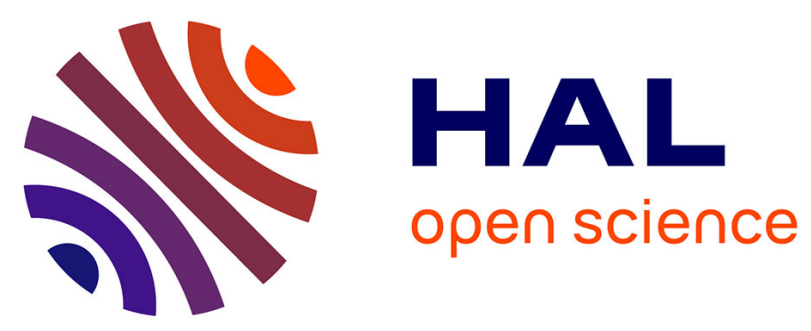

\title{
Direct Grafting of Free-Base meso -Triarylporphyrins on Electrode Materials through Diazonium Reduction: Reversible Zinc(II) Metallation of the Resulting Materials
}

Seydou Hebié, Charles H. Devillers, Sophie Fournier, Dominique Lucas

\section{To cite this version:}

Seydou Hebié, Charles H. Devillers, Sophie Fournier, Dominique Lucas. Direct Grafting of Free-Base meso -Triarylporphyrins on Electrode Materials through Diazonium Reduction: Reversible Zinc(II) Metallation of the Resulting Materials. ChemElectroChem, 2016, 3 (1), pp.45-50. 10.1002/celc.201500433 . hal-03471725

\section{HAL Id: hal-03471725 \\ https://hal.science/hal-03471725}

Submitted on 8 Dec 2021

HAL is a multi-disciplinary open access archive for the deposit and dissemination of scientific research documents, whether they are published or not. The documents may come from teaching and research institutions in France or abroad, or from public or private research centers.
L'archive ouverte pluridisciplinaire HAL, est destinée au dépôt et à la diffusion de documents scientifiques de niveau recherche, publiés ou non, émanant des établissements d'enseignement et de recherche français ou étrangers, des laboratoires publics ou privés. 


\section{Direct grafting of free base meso-triarylporphyrins on GC, ITO and Pt via 5-diazonium-triarylporphyrin electroreduction. Reversible zinc(II)-metallation of the resulting materials}

\begin{abstract}
Electroreduction of free base meso-diazoniumtriarylporphyrins, generated in situ from their corresponding mesoaminotriarylporphyrin precursors, leads to the formation of a covalently grafted porphyrin film. In this new material, contrary to recently published results, the free base porphyrin core is directly bonded to the surface, i.e. without any spacer such as phenyl fragments. These thin films are characterized by cyclic voltammetry (CV), UV-Visible absorption spectroscopy and water angle contact. The electrochemical response is in agreement with a multilayer structure. Efficient and reversible zinc metallation of the immobilized porphyrin units is readily achieved opening the door to numerous applications in sensing and electrocatalysis.
\end{abstract}

Seydou Hebié ${ }^{[a]}$ Charles H. Devillers, ${ }^{*[a]}$ Sophie Fournier ${ }^{[a]}$ and Dominique Lucas ${ }^{*[a]}$
Porphyrin-based thin films are attractive in many scientific fields and for many applications given their interesting physicochemical properties. They have been integrated in nonlinear optical and optical limiting devices, ${ }^{[1]}$ photoluminescent biosensors, ${ }^{[2]}$ molecular electronic junctions ${ }^{[3]}$ and electrocatalytic systems. ${ }^{[4]}$ Because of these important applications, modification of electrodes with porphyrins and metalloporphyrins is currently intensely investigated. To date, numerous approaches have been developed to deposit the porphyrin moiety on various substrates. These approaches include chemisorption, ${ }^{[5]}$ physisorption, ${ }^{[6]}$ self-assembly through tethered functional groups, ${ }^{[7]}$ thermolysis, ${ }^{[8]}$ click chemistry, ${ }^{[9]}$ oxidation of terminal alkyne substituents, ${ }^{[10]}$ anodic electropolymerization ${ }^{[11]}$ and covalent attachment through the cathodic electroreduction of diazonium salts. ${ }^{[12]}$ Surface modification via aryl diazonium salts is particular promising since this method allows a fine control of the thickness of the deposited layer (mono- and multilayer films) and is compatible with a wide range of substrates. Basically the electrode reaction involves a one-electron transfer onto the aryl diazonium cation, which is followed by elimination of $\mathrm{N}_{2}$ to give a highly reactive aryl radical. This one adds to the surface thus forming the covalent bond. ${ }^{[12 a, 12 b, 13]}$ This reaction has been investigated in organic $^{[12 a]}$ and aqueous media ${ }^{[12 b]}$ and in ionic liquids ${ }^{[13 b]}$ using various materials and several aryl derivatives. Only three manuscripts have dealt with the electrografting of porphyrins from diazonium precursors so far. ${ }^{[12 a, 12 b, 14]}$ Firstly Gross et al. ${ }^{[12 a]}$ and Picot et al. ${ }^{[12 b]}$ have reported on the electrografting of tetraphenylporphyrin to electrode surfaces through a para-

[a] Dr. S. Hebié, Dr. C. H. Devillers, S. Fournier, Prof. Dr. D. Lucas ICMUB UMR6302, CNRS, Univ. Bourgogne Franche-Comté, F21000 Dijon, France.

E-mail: charles.devillers@u-bourgogne.fr; dominique.lucas@ubourgogne.fr

Supporting information for this article is given via a link at the end of the document.

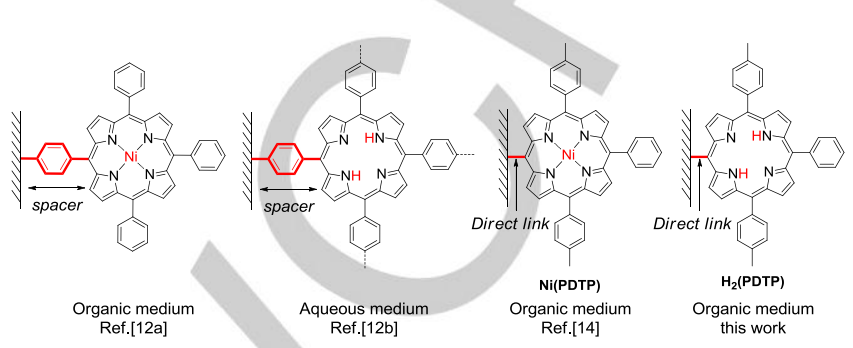

Scheme 1. Existing electrode derivatizations by porphyrins obtained through electroreduction of diazonium porphyrins.

phenylene spacer (see Scheme 1). More recently, we performed the direct covalent grafting on platinum electrode of the nickel(II) 15-phenyl-10,20-ditolylporphyrin complex (Ni(PDTP), Scheme 1) via the electroreduction of the corresponding meso-diazonium salt, in situ generated from its meso-aminoporphyrin precursor. ${ }^{[14]}$ Although the direct connection of the porphyrin core to the electrode surface is a novel feature which could offer new opportunities, this modified electrode might suffer from the difficulty to remove the $\mathrm{Ni}(\mathrm{II})$ center and/or to change it with another metal. Indeed the porphyrin metal center strongly delimits the physico-chemical properties of the modified electrode. Therefore, the possibility to introduce any metal inside the macrocycle is desirable for access to a broader scope of applications. For such a purpose, the free base form of the porphyrin seems to be the most suitable as it can be transformed in a variety of metal complexes.

We thus report in this communication the unprecedented direct and covalent grafting of a meso-triaryl free base porphyrin $\mathbf{H}_{2}$ (PDTP) (structure on the right in Scheme 1) on diverse supporting materials, by electrochemical reduction of the corresponding meso-diazonium salt $\left(\mathbf{H}_{2}\left(\mathbf{P D T P}-\mathbf{N}_{2}{ }^{+}\right)\right.$. Further, as a proof of concept, being immobilized on the surface, the free base porphyrin can be converted quantitatively, but reversibly, into its zinc complex. Both porphyrin functionalized materials have been characterized by UV-Visible absorption spectroscopy, cyclic voltammetry (CV) and water angle contact.

The main steps leading to the electrodeposition of $\mathbf{H}_{2}$ (PDTP) on an electrode surface are depicted in Figure 1a. In a first step, diazotation of the aminoporphyrin precursor with $\mathrm{NaNO}_{2}$ and TFA generates the diazonium porphyrin salt $\mathbf{H}_{2}\left(\right.$ PDTP- $\mathbf{N}_{2}{ }^{+}$), most probably in its protonated form, i.e. $\mathbf{H}_{4}\left(\right.$ PDTP- $\left.\mathbf{N}_{2}{ }^{+}\right)$, due to the acidic conditions used. Thereafter, the monoelectronic reduction of the latter via multiple potential cycling produces the neutral radical which covalently bonds to the electrode surface material. The multiple sweep cyclic voltammogram of the in situ generated diazonium $\mathbf{H}_{4}\left(\right.$ PDTP- $\mathbf{N}_{2}{ }^{+}$) recorded on glassy carbon (GC) electrode at $50 \mathrm{mV} \mathrm{s}^{-1}$ in acetonitrile (ACN) $0.1 \mathrm{M} \mathrm{TEABF}_{4}$ with a potential scan initially going negative is presented in Figure $1 \mathrm{~b}$. The first scan shows a 
broad peak at $E_{\mathrm{pc}}=0.25 \mathrm{~V}$ which is accompanied by a prepeak at $E_{p c}=0.42 \mathrm{~V}$. The former at the most negative potential corresponds to the irreversible one-electron reduction of the in situ generated diazonium cation, in conformity with the voltammetric response commonly observed for the reduction of aromatic and porphyrin diazonium salts. ${ }^{[12 a, 13 a]}$ As in our case, a prepeak is very often observed in the voltammogram although its origin remains not well understood yet. ${ }^{[15]}$ On the second scan between 0.5 and $0.05 \mathrm{~V}$, in the $\mathrm{CV}$ of $\mathbf{H}_{4}(\mathrm{PDTP})-\mathrm{N}_{2}{ }^{+}$(Figure 1c), the two reduction peaks have practically disappeared. By pursuing the potential cycling, the reduction current keeps on decreasing in accordance with the formation of a passivating film blocking electron transfer between the electrode and $\mathbf{H}_{4}$ (PDTP$\mathbf{N}_{2}{ }^{+}$) in solution. This CV evolution is rather typical of the electrochemical reduction of aryl diazonium salts for which the formation and growth of the grafted organic layer progressively limits and finally extinguish further reduction of the diazonium cations. ${ }^{[13 a, 16]}$ This process was similar in the previous studies on the reduction in acetonitrile of porphyrin diazonium salts. ${ }^{[12 a,}$ 14] Noteworthy, scanning through the $0.4 \mathrm{~V}$ peak (from 0.5 to $0.35 \mathrm{~V}$ vs. SCE, 30 scans) also leads to the modification of the electrode but with much lower efficiency. Indeed, after transfer of this modified electrode into a blank solution, the electrochemical response is similar as for the deposition with the larger potential scan (see description below) but with a considerably reduced intensity $(17 \%$ of the signal collected for the material prepared through scanning from 0.5 to $0.05 \mathrm{~V} / \mathrm{SCE})$. This control experiment confirms that the reduction of the diazonium moiety occurs mainly at the peak centered at $0.25 \mathrm{~V}$.

Table 1. Electrochemical characterization of $\mathbf{H}_{2}(\mathrm{PDTP}), \mathrm{Zn}(\mathrm{PDTP})$ and $\mathrm{Ni}(\mathrm{PDTP})$ films, all deposited on glassy carbon (GC). ${ }^{\left[{ }^{[]}\right.}$

\begin{tabular}{|c|c|c|c|}
\hline Material & $\mathrm{H}_{2}$ (PDTP) & Zn(PDTP) & $\mathrm{Ni}(\mathrm{PDTP})$ \\
\hline$E_{1 / 2}(\operatorname{red} 2)(\mathrm{V})^{[\mathrm{b}]}$ & -1.51 & & $-1.34^{[\mathrm{e}]}$ \\
\hline$E_{1 / 2}(\operatorname{red} 1)(\mathrm{V})^{[\mathrm{b}]}$ & -1.11 & -1.44 & $-0.95^{[\mathrm{e}]}$ \\
\hline$E_{1 / 2}(\mathrm{ox} 1)(\mathrm{V})^{[\mathrm{b}]}$ & 1.18 & 0.90 & $1.32^{[f]}$ \\
\hline$E_{1 / 2}(\mathrm{ox} 2)(\mathrm{V})^{[\mathrm{b}]}$ & & 1.20 & \\
\hline $\begin{array}{l}\text { HOMO-LUMO gap } \\
\left(E_{1 / 2}\left(\mathrm{ox}_{1}\right)-E_{1 / 2}\left(\mathrm{red}_{1}\right)\right)(\mathrm{V})\end{array}$ & 2.29 & 2.34 & 2.27 \\
\hline Stability $^{[\mathrm{c}]}$ & $-37 \%$ & $-27 \%$ & \\
\hline$\Gamma\left(\times 10^{10} \mathrm{~mol} \mathrm{~cm}^{-2}\right)^{[\mathrm{d}]}$ & $12 \pm 1$ & $11 \pm 1$ & $2 \pm 1^{[f]}$ \\
\hline
\end{tabular}

[a] Unless otherwise noted, voltammetric data are recorded in acetonitrile $\left(0.1 \mathrm{M} \mathrm{TEABF}_{4}\right)$ at $1 \mathrm{~V} \mathrm{~s}^{-1}$ on $\mathrm{GC}$; all potentials are referred to the saturated calomel electrode (SCE). [b] $E_{1 / 2}$, the half-wave potential, is taken as the half-sum of the forward and backward peak potentials of a given system. [c] \% of charge decrease between the $2^{\text {nd }}$ and $100^{\text {th }}$ cycles for the better resolved peak $\left(2^{\text {nd }}\right.$ reduction peak for $\mathbf{H}_{2}$ (PDTP) and $1^{\text {st }}$ oxidation peak for $\mathrm{Zn}($ PDTP) and $\mathrm{Ni}($ PDTP)). [d] Surface coverage calculated from the integration of the $2^{\text {nd }}$ cycle CV peak considering a monoelectronic electron transfer $\left(2^{\text {nd }}\right.$ reduction peak for $\mathbf{H}_{2}$ (PDTP) and $1^{\text {st }}$ oxidation peak for $\mathrm{Zn}(\mathrm{PDTP})$ and Ni(PDTP)). [e] Measured in DMF. [f] Measured in $\mathrm{CH}_{2} \mathrm{Cl}_{2}$.

After the period of scanning, the modified electrodes are consecutively sonicated in a $0.1 \mathrm{M} \mathrm{NH}_{3}$ water solution and in pure $A C N$. Then, after transfer into a $0.1 \mathrm{M} \mathrm{TEABF}_{4} / \mathrm{ACN}$ solution, cyclic voltammograms of the GC modified electrode are recorded in the anodic and cathodic directions (Figure 1c). Two well-defined reversible monoelectronic reductions are observed at $\left(\mathrm{R} 2 / \mathrm{O} 2, E_{1 / 2}=-1.11 \mathrm{~V}\right)$ and $\left(\mathrm{R} 3 / \mathrm{O} 3, E_{1 / 2}=-1.51 \mathrm{~V}\right)$. These values and the potential gap between the first and second reductions $\left(\Delta E_{1 / 2}=E_{1 / 2}(\right.$ red1 $)-E_{1 / 2}($ red2 $\left.)=0.40 \mathrm{~V}\right)$, as well as the reversibility criterion are reminiscent to those reported for free base porphyrins in solution. ${ }^{[17]}$ The reduction processes can be thus attributed to the successive formation of the radical anion and dianion of the grafted porphyrin. For each redox process, the peak-to-peak separations $\left(\Delta E_{\mathrm{p}}=E_{\mathrm{pc}}-E_{\mathrm{pa}}\right)$ are 101 $\mathrm{mV}$ and $96 \mathrm{mV}$, respectively, at the scan rate of $1 \mathrm{~V} \mathrm{~s}^{-1}$. In the positive potential region, an oxidation occurs at $\left(\mathrm{R} 1 / \mathrm{O} 1, E_{1 / 2}=\right.$ $+1.18 \mathrm{~V}$ ). This signal is assigned to the first oxidation of the electrode-linked porphyrin since the potential gap between the first oxidation and first reduction $\left(\Delta E_{1 / 2}=1.18-(-1.11)=2.29\right.$ V) perfectly

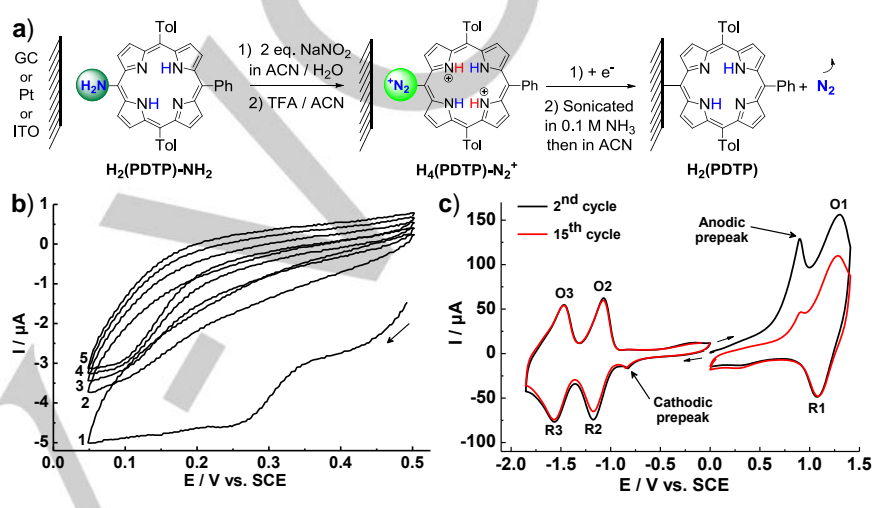

Figure 1. a) In situ generation of $\mathbf{H}_{4}\left(\right.$ PDTP- $\mathbf{N}_{2}{ }^{+}$) followed by electrochemical grafting on the electrode surface. b) First five grafting scans at $\mathrm{GC}$ of $1 \mathrm{mM}$ $\mathrm{H}_{4}\left(\mathrm{PDTP}_{-} \mathrm{N}_{2}{ }^{+}\right)$in $0.1 \mathrm{M} \mathrm{TEABF}_{4} / \mathrm{ACN}$ containing $\mathrm{NaNO}_{2}$ and TFA $(v=50 \mathrm{mV} \mathrm{s}$ 1 , RT). c) CVs of a derivatized GC electrode, reduction and oxidation of $\mathbf{H}_{2}$ (PDTP)/GC film prepared by 30 grafting cycles: second scan (black curve), fifteenth scan (red curve); conditions: $0.1 \mathrm{M} \mathrm{TEABF}_{4} / \mathrm{ACN}, v=1 \mathrm{~V} \mathrm{~s}^{-1}$ at RT.

matches the common characteristic potential gap for porphyrins $\left(\Delta E=2.25 \pm 0.15 \mathrm{~V}^{[17]}\right)$. For the redox couples $\mathrm{R} 1 / \mathrm{O} 1, \mathrm{R} 2 / \mathrm{O} 2$ and $\mathrm{R} 3 / \mathrm{O} 3$, the ratio between the oxidation and reduction peak currents at any given scan rate is close to unity. Additionally, the CV shows prepeaks at the foot of the macrocycle reduction and oxidation waves (at $-0.82 \mathrm{~V}$ and $0.93 \mathrm{~V}$, respectively). Similar features have been observed in the voltammetric response of other semi-conducting porphyrin containing thick films. ${ }^{[18]}$ Their origin is the change in film resistivity induced by the reversible oxidation or reduction of the immobilized redox groups. ${ }^{[19]}$ It has been shown that the occurrence and intensity of these prepeaks are highly dependent on the potential scan limits, which is also verified in the case of our GC modified electrode (see ESI S9, Fig. 14). In addition, redox processes of $\mathbf{H}_{2}$ (PDTP) films are strongly solvent dependent as the first oxidation system is chemically irreversible in DMF and DCM but shows a better reversibility in ACN (see ESI S5-S6, Fig. 6 and 7). The electrografting of $\mathbf{H}_{2}$ (PDTP) proceeds as well on ITO and $\mathrm{Pt}$ surfaces (see ESI S3, Fig. 2). The voltammetric responses of the resulting modified electrodes are very similar to the one obtained on GC (see ESI S4-S5, Fig. 3 and 5). The electrochemical stability of $\mathbf{H}_{\mathbf{2}}$ (PDTP) on the different supporting materials was investigated by repeatedly scanning the electrode potential at $1 \mathrm{~V} \mathrm{~s}^{-1}$ over the reduction or oxidation zones. For all modified electrodes, on the first cycle, the intensity of the reduction peaks are 5 to $12 \%$ larger than on the second cycle which is probably because of the desorption of some non- 
WILEY-VCH

covalently bonded porphyrin molecules. After the first cycle the voltammograms are virtually persistent during potential cycling though a slight decrease in the peak area is observed between the $2^{\text {nd }}$ and $100^{\text {th }}$ cycles. In the cathodic range, on GC, the loss percentage is $-37 \%$ (see Table 1). Interestingly, in the same conditions, $\mathbf{H}_{\mathbf{2}}$ (PDTP) films on platinum electrodes and ITO were found to be more stable in the negative potential range $(-13 \%$ and $-19 \%$, respectively, see ESI S5, Fig. 3 and 5). The electrochemical stability of $\mathbf{H}_{2}$ (PDTP) during multiple scans has also been tested at $0.1 \mathrm{~V} \mathrm{~s}^{-1}$ but the peak intensities rapidly dropped with full loss of the porphyrin redox features after only 13 cycles between 0.00 and $-1.80 \mathrm{~V}$ (see ESI S10, Fig. 15).

The surface coverage $\Gamma$ of electroactive porphyrins grafted on the modified electrodes has been determined measuring the area under the peaks of the either oxidative or reductive forward scan and using Faraday's law. ${ }^{[12 a]}$ For $\mathbf{H}_{2}$ (PDTP) films, $\Gamma$ reaches a limiting value, $\Gamma_{\max }$, after $30 \mathrm{CV}$ depositing scans in the diazonium porphyrin solution. Thereby, $\Gamma_{\max }$ values are $9 \pm 1 \times 10$ ${ }^{10}, 12 \pm 1 \times 10^{-10}$ and $11 \pm 1 \times 10^{-10} \mathrm{~mol} \mathrm{~cm}^{-2}$ for ITO, GC and Pt supported electrodes, respectively (see ESI S9, Fig.13). These surface coverages are larger than the one expected for a porphyrin monolayer (about $2.2 \times 10^{-10} \mathrm{~mol} \mathrm{~cm}^{-2}$, determined according to the crystallographic structure of zinc(II) 10-phenyl5,15-ditolylporphyrin ${ }^{[20]}$ and considering an orthogonal and compact arrangement of the porphyrins vs. the supporting material plane). These results indicate that the $\mathbf{H}_{2}$ (PDTP) film is built from a multilayer of porphyrins (ca. 4 to 6 layers). Possible sites for the porphyrin chain elongation are the unencumbered positions of the 15-phenyl group. It is well known that unprotected aryl diazonium salts $\left(\mathrm{Ar}-\mathrm{N}_{2}{ }^{+}\right)$give rise to the formation of thicker multilayered films. The mechanism involves secondary additions of the aryl radical or the diazonium cation onto the aryl backbone of the grafted molecules. ${ }^{[12 c, 13 a]}$ It must be underlined that, for the Ni(PDTP) film, although electrodeposited in identical conditions, $\Gamma_{\max }$ is much lower (on GC, reduction by a factor of 10 ; see Table 1) and corresponds to the monolayer state. ${ }^{[14]}$ We have no detailed explanation for this difference yet. Possibly it could originate from an exalted reactivity of the $\mathbf{H}_{2}$ (PDTP) system, in relation with the protonation of the macrocycle which occurs in the highly acidic electrografting conditions.

The ability of the modified electrode to mediate electron transfer with a redox couple in solution was studied. The response of the 7,7,8,8-tetracyano-p-quinodimethane (TCNQ) redox probe was measured on bare and porphyrin modified GC electrodes (Figure 2). This molecule was chosen since it exhibits a one-electron reversible peak system at $E_{1 / 2}=0.194 \mathrm{~V}$ in a potential range where the porphyrin material is not electroactive. Going from the bare to the grafted electrode (see Fig. 2), the forward peak current $\left(I_{p c}\right)$ significantly decrease (ca. $-30 \%$ ) whereas the peak-to-peak separation $\Delta E_{\mathrm{p}}=E_{\mathrm{pa}}-E_{\mathrm{pc}}$ slightly increases (ca. 17\%). This evolution denotes a partial electron transfer blockage by the porphyrin film. ${ }^{[1]}$ Typically, this behavior indicates that the redox probe diffuses through pinholes of the film for being reduced at the GC active surface. ${ }^{[22]}$

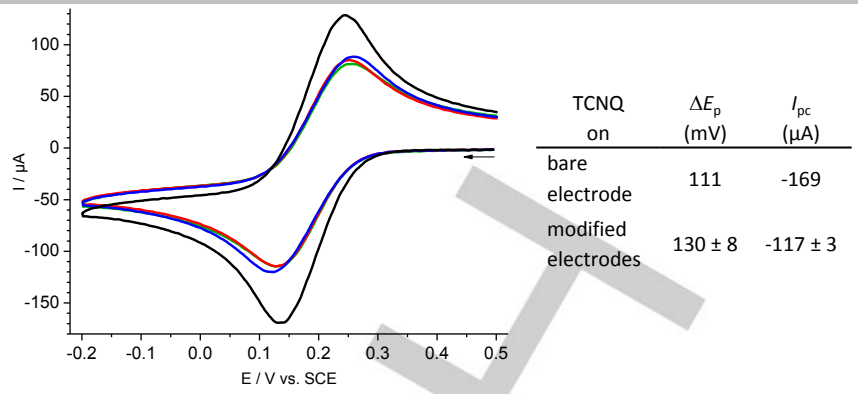

Figure 2. CVs of a bare electrode (black curve) and derivatized GC electrodes (resulting from the electrodeposition of the diazonium on three different GC electrodes; blue, red and green curves) in a $0.1 \mathrm{M} \mathrm{TEABF} / \mathrm{ACN}$ solution containing $1 \mathrm{mM}$ of TCNQ $\left(v=1 \mathrm{~V} \mathrm{~s}^{-1}\right.$ at RT). The modified electrodes have been cycled two times between $0.00 \mathrm{~V}$ and $-1.80 \mathrm{~V}$ in a $0.1 \mathrm{M} \mathrm{TEABF}_{4} / \mathrm{ACN}$ solution before performing this experiment.

As outlined above, for such porphyrin based material, an important advantage is the easiness to introduce any metal in the macrocycle in order to reach a specific application. In this prospect, the $\mathbf{H}_{2}$ (PDTP) film grown in our conditions can be readily converted into the zinc complex form by immersion in a saturated $\mathrm{Zn}(\mathrm{OAc})_{2}$ solution in $\mathrm{MeOH} /$ chloroform $(1: 9, \mathrm{v} / \mathrm{v})$ during $15 \mathrm{~min}$. at $60{ }^{\circ} \mathrm{C}$ (Figure $3 \mathrm{a}$ ). The reaction proceeds faster than in the conditions described by M.V. Sheridan et al. ${ }^{[10]}$ for a similar porphyrin grafted material (treatment overnight with a solution of $\mathrm{ZnCl}_{2}(1 \mathrm{M})$ in diethylether). After sonication in pure $\mathrm{ACN}$ and transfer into $\mathrm{ACN}$ containing the supporting electrolyte, the $\mathrm{CV}$ of the treated electrode is characterized by two consecutive well-defined reversible monoelectronic oxidations at $0.90 \mathrm{~V}$ and 1.20 V/SCE and one reversible monoelectronic reduction at $-1.44 \mathrm{~V} / \mathrm{SCE}$ (Figure $3 \mathrm{~b}$, middle). These features are consistent with zinc insertion which, expectedly, increases the electronic density of the porphyrin core making its oxidation easier and its reduction more difficult as compared to the free base porphyrin. ${ }^{[17,23]}$ These redox systems are preceded by two prepeaks, observed at $-1.20 \mathrm{~V}$ and $0.70 \mathrm{~V} / \mathrm{SCE}$. Besides, the potential bandgap between the first reduction and the first oxidation peaks is very close to the one measured for the free base porphyrin film $\left(\Delta E_{1 / 2}=2.34 \mathrm{~V}\right.$ and $\Delta E_{1 / 2}=2.29 \mathrm{~V}$, respectively). In that way, the response of the zinc porphyrin modified electrode matches the common behavior of metalloporphyrins with a non-electroactive metal in solution. ${ }^{[10,17}$, ${ }^{20,24]}$ In addition, after the metallation step, the surface coverage $\Gamma$ of $\mathrm{Zn}$ (PDTP) was estimated at $11 \pm 1 \times 10^{-10} \mathrm{~mol} \mathrm{~cm}^{-2}$ on the GC supported electrode. This value is very close to the one found before treatment $\left(12 \pm 1 \times 10^{-10} \mathrm{~mol} \mathrm{~cm}^{-2}\right)$, suggesting that the metallation is almost complete and that the structure remains nearly intact during the metallation process (porphyrin core molecule-electrode link). From the $\mathrm{H}_{2}$ (PDTP) to the $\mathrm{Zn}(\mathrm{PDTP})$ film, the stability over potential cycling is slightly improved (loss of peak area evolving from $-37 \%$ to $-27 \%$ after 100 consecutive cycles, see Table 1 and ESI). Notably, the free base porphyrin film can be easily recovered from the $\mathrm{Zn}$ form as evidenced by cyclic voltammetry (Figure $3 b$, bottom) by dipping the zinc porphyrin modified electrode in a diluted $\mathrm{HCl} / \mathrm{ACN}$ solution $(0.2$ $\mathrm{mol} \mathrm{L}^{-1}$ ) for $5 \mathrm{~min}$. at RT.

The electrografting and metallation processes of the film are confirmed by UV-visible absorption spectroscopy measurements on indium tin oxide (ITO) slides (Figure 3c). After electrodeposition of the free base porphyrin, the spectrum of the modified ITO electrode, which is visibly covered by a green and 
adherent thin film, shows the characteristic Soret band at 431 $\mathrm{nm}$ and four $\mathrm{Q}$ bands respectively at 525, 562, 601 and 659 $n m .^{[12 b]}$ After zinc metallation of the free base film, the bathochromically shifted Soret band appears at $437 \mathrm{~nm}^{[10,25]}$ and only two $Q$ bands (at 564 and $605 \mathrm{~nm}$ ) remain. These features are typical of the metal insertion. Besides, the Soret band
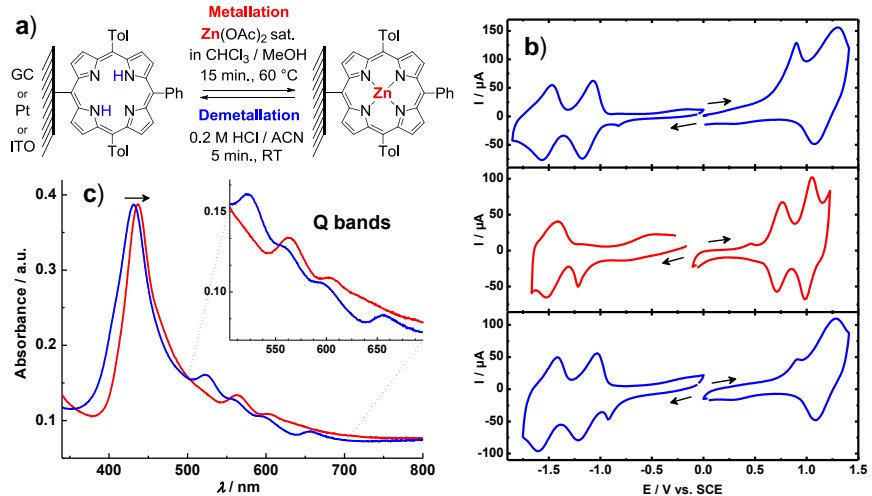

Figure 3. a) Metallation and demetallation processes of the $\mathbf{H}_{2}($ PDTP $)$ functionalized electrode. b) Second scan CVs of the free base modified GC electrode (blue curve, top), after $\mathrm{Zn}(\mathrm{OAc})_{2}$ treatment (red curve, middle) and after diluted $\mathrm{HCl}$ treatment (blue curve, bottom) (in $0.1 \mathrm{M} \mathrm{TEABF}_{4} / \mathrm{ACN}, v=1 \mathrm{~V}$ $\mathrm{s}^{-1}$ ). c) UV/Vis spectra of a $\mathrm{H}_{2}$ (PDTP) modified ITO electrode before (blue curve) and after $\mathrm{Zn}(\mathrm{OAc})_{2}$ treatment (red curve).

maximum absorbances of the free base and metallated porphyrin materials are identical which constitutes an additional proof that the metallation is nearly complete and that the structure is kept intact during the metallation process. Indeed, the molar extinction coefficient is expected to be practically identical for these two species. ${ }^{[26]}$

The water contact angle characterization of modified electrodes gives additional evidence of the surface modification. ${ }^{[27]}$ In our case, the contact angle of a water droplet on ITO increases from $40^{\circ}$ (unmodified electrode) to $53^{\circ}, 57^{\circ}$ and $55^{\circ}$ for $\mathbf{H}_{2}$ (PDTP), $\mathbf{Z n}($ PDTP) and $\mathbf{N i ( P D T P )}$ films, respectively (see Figure 4). The presence of hydrophobic fragments such as phenyl and tolyl groups as well as the porphyrin core itself may be responsible for the increase of the contact angle. This result demonstrates that the porphyrin deposition provides a hydrophobic layer on the ITO substrate.

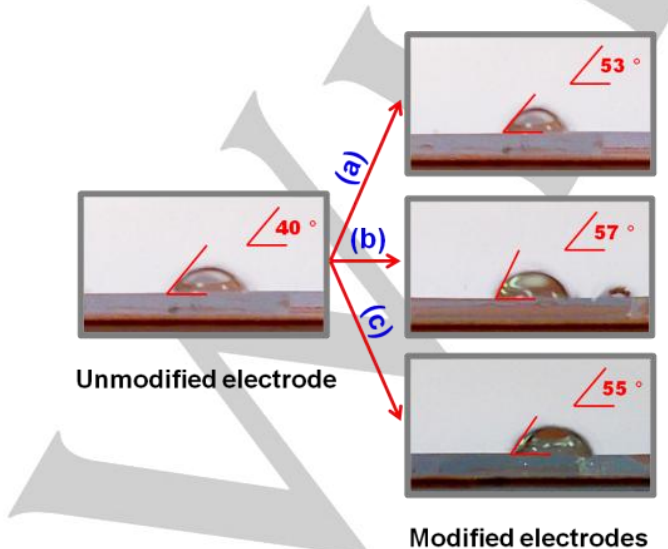

Figure 4. Photographs of a $10 \mu \mathrm{L}$ water droplet on the surface of ITO unmodified and modified electrodes surface: (a) $\mathbf{H}_{\mathbf{2}}$ (PDTP) film, (b) $\mathbf{Z n}$ (PDTP) film, (c) Ni(PDTP) film.
In summary, the unprecedented direct covalent attachment of meso-triaryl free base porphyrins on GC, Pt and ITO electrodes has been achieved via electroreduction of its mesodiazonium precursor. Besides, efficient zinc(II) metallation of the resulting material has been performed. The grafted films exhibit porphyrin-like UV-visible absorption spectra and CV, which indicates that the porphyrin structure is retained inside. The limiting surface coverage of the films suggests that contrary to what was observed for electrografted meso-triaryl nickel(II) porphyrins which form a film close to a monolayer, the free base porphyrins deposit as a multilayer on the electrode surface. This new porphyrin functionalized material offers promising possibilities of applications, in particular for sensing and electrocatalysis, since it could potentially be metallated with various metals. These applications are currently under investigation.

\section{Experimental Section}

Tetraethylammonium tetrafluoroborate $\left(\mathrm{TEABF}_{4}\right)$ was synthesized by the following method. Typically, in a $500 \mathrm{~mL}$ Erlenmeyer flask, $84.28 \mathrm{~g}$ of tetrafluoroboric acid, $\mathrm{HBF}_{4}$ (Sigma Aldrich, 48\% $\mathrm{H}_{2} \mathrm{O}$ ) was mixed with $193.84 \mathrm{~g}$ of a solution of tetraethylammonium hydroxide, TEAOH (Alfa Aesar, $35 \% \mathrm{H}_{2} \mathrm{O}$ ). The reaction mixture was continuously stirred under air atmosphere. Then, the white precipitate formed after cooling the flask in an ice bucket was filtered on a Buchner. Finally, the residue was crystallized from $\mathrm{MeOH}$ under reflux, cooled in a freezer at $-18{ }^{\circ} \mathrm{C}$, filtered on a Buchner and dried at $110{ }^{\circ} \mathrm{C}$ in the stove for at least two days before use. $\mathrm{CH}_{2} \mathrm{Cl}_{2}$ (Carlo Erba 99.5\%), $\mathrm{CH}_{3} \mathrm{CN}$ (SDS, Carlo Erba HPLC gradient 99.9\%) were distilled from $\mathrm{P}_{2} \mathrm{O}_{5}$ and $\mathrm{CaH}_{2}$ respectively. $\mathrm{H}_{2}\left(\right.$ PDTP-NH $\mathrm{N}_{2}$ ) was prepared as described previously (see reference 16 of the manuscript). UV-visible absorption spectra were recorded with a Varian UV-vis spectrophotometer Cary 50 scan. All voltammetric experiments were run on indium tin oxide (ITO) plate (from Sigma-Aldrich, surface resistivity $8-12 \Omega / \mathrm{sq}$ ), geometric area $S_{g}=0.4 \mathrm{~cm}^{2}$ ), platinum and glassy carbon disks electrodes $(\varnothing=2 \mathrm{~mm}, 3 \mathrm{~mm}$ respectively). The ITO plates were cleaned by sonication first with acetone $(10 \mathrm{~min})$, then with dichloromethane (10 $\mathrm{min})$ and finally with water (2 min, several times) while the platinum and glassy carbon disks were polished with diamond polishing slurries, rinsed with distilled water and dried using $\operatorname{Ar}(\mathrm{g})$. The reactions were performed in a conventional three-electrode cell using Schlenk techniques in an atmosphere of dry oxygen-free argon at room temperature $\left(\mathrm{T}=20^{\circ} \mathrm{C} \pm 3^{\circ} \mathrm{C}\right)$. The supporting electrolyte was degassed under vacuum before use. Voltammetric analyses were carried out with an Autolab PGSTAT 302N potentiostat, connected to an interfaced computer that employed Electrochemistry Nova software. A double junction saturated calomel electrode (SCE) with background electrolyte between the two frits, was used as reference electrode. The auxiliary electrode was a platinum wire in an independent compartment filled with the background electrolyte and separated from the analyzed solution by a sintered glass disk. In these conditions, when operating in $\mathrm{CH}_{3} \mathrm{CN}(0.1$ $\left.\mathrm{M} \mathrm{TEABF}_{4}\right)$ or in $\mathrm{CH}_{2} \mathrm{Cl}_{2}\left(0.1 \mathrm{M} \mathrm{TEABF}_{4}\right)$ the formal potential for the $\mathrm{FC}^{+} / \mathrm{Fc}$ couple was found to be $+0.40 \mathrm{~V}$ or $+0.52 \mathrm{~V} / \mathrm{vs}$. SCE, respectively. Prior to each electrochemical measurement the solutions were deoxygenated by bubbling argon gas for $20 \mathrm{~min}$, during the experiment the electrochemical cell remains under argon.

All electrode materials (ITO, C and Pt) were modified similarly by electroreduction of $\mathrm{H}_{4}\left(\mathrm{PDTP}-\mathrm{N}_{2}{ }^{+}\right)$in situ generated from $\mathrm{H}_{2}\left(\mathrm{PDTP}-\mathrm{NH}_{2}\right)$. Porphyrin diazonium was generated in acidic aqueous media (TFA) by reaction of the $\mathrm{H}_{2}\left(\mathrm{PDTP}-\mathrm{NH}_{2}\right)(1 \mathrm{mM})$ with 2 equivalent of $\mathrm{NaNO}_{2}$ in the dark under an argon atmosphere. Typically, in a clean conventional three electrodes cell, appropriate quantities of reactants were placed, namely $5.8 \mathrm{mg}(10 \mu$ mole $)$ of $\mathrm{H}_{2}\left(\right.$ PDTP- $\left.\mathrm{NH}_{2}\right)$ and $1 \mathrm{~mL}$ of $\mathrm{ACN}$ under argon. After complete dissolution ( $c$. five minutes), a mixture containing $1.4 \mathrm{mg}$ of $\mathrm{NaNO}_{2}$ (2 eq.), $20 \mu \mathrm{L}$ of $\mathrm{H}_{2} \mathrm{O}$ and $80 \mu \mathrm{L}$ of $\mathrm{ACN}$ was added dropwise to the porphyrin solution under argon. The use of a small amount of water 
enhances the solubility of $\mathrm{NaNO}_{2}$ in $\mathrm{ACN}$. After 15 min, a mixture of 170 $\mu \mathrm{L}$ of TFA and $830 \mu \mathrm{L}$ of a $0.11 \mathrm{M} \mathrm{TEABF} / \mathrm{ACN}$ solution were added. Finally, $7.9 \mathrm{~mL}$ of a $0.11 \mathrm{M} \mathrm{TEABF} / \mathrm{ACN}$ solution was added in the cell. The solution was purged with argon for $10 \mathrm{~min}$ prior to reductive adsorption and was kept under a blanket of argon during all the process of surface modification. Once the diazotation reaction is completed, the diazonium cation is reduced on the electrode by multiple scan voltammetry by cycling between 0.5 and $0.05 \mathrm{~V}$ versus the $\mathrm{KCl}$ Saturated Calomel Electrode (SCE) along thirty recurrent cycles at room temperature and at $50 \mathrm{mV} \mathrm{s}^{-1}$. After modification step, the electrode was sonicated $30 \mathrm{~s}$ in a $0.1 \mathrm{M}$ aqueous $\mathrm{NH}_{3}$ solution, rinsed with distilled water and sonicated in DMF for $30 \mathrm{~s}$ (or DCM or ACN, for subsequent analysis using DCM or ACN, respectively) and transferred in the second cell previously containing the deaerated suitable supporting electrolyte. We recommend performing the electrodeposition during the first hour which follows the diazotation reaction since it is less efficient after and does not work anymore after two hours. Anhydrous ACN, DMF and dichloromethane (DCM) were used for solution preparation and rinsing. The modified electrodes were characterized by cyclic voltammetry in 0.1 $\mathrm{M} \mathrm{TEABF}_{4} / \mathrm{DCM}, 0.1 \mathrm{M} \mathrm{TEABF}_{4} / \mathrm{ACN}$ and $0.1 \mathrm{M} \mathrm{TEABF}_{4} / \mathrm{DMF}$.

Water contact angle characterization involves measuring the angle of the tangent of the profile of a drop deposited on the substrate, with the substrate surface. In practice, a drop of $10 \mu \mathrm{L}$ of ultra-pure water is deposited using a syringe on the surface of the same ITO electrode plate before and after its modification

\section{Acknowledgements}

The authors acknowledge the Université de Bourgogne, the Conseil Régional de Bourgogne (CRB) and the Centre National de la Recherche Scientifique (CNRS) for funding. S.H. is particularly grateful to the $\mathrm{CRB}$ for his research grant (convention $n^{\circ}$ : B190CVHCP-2013). C.H.D. thanks the CNRS for letting him the opportunity to work as a full time researcher for one year ("délégation CNRS", Sept. 2015).

Keywords: Diazonium electroreduction - Molecular electrochemistry • Porphyrinoids • Thin films • Surface chemistry

[1] A. Wang, Y. Fang, L. Long, Y. Song, W. Yu, W. Zhao, M. P. Cifuentes, M. G. Humphrey, C. Zhang, Chem. Eur. J. 2013, 19, 14159-14170.

[2] R. F. Khairutdinov, N. Serpone, J. Phys. Chem. B 1999, 103, 761-769.

[3] a) R. L. McCreery, Chem. Mater. 2004, 16, 4477-4496; b) A. P. Bonifas, R. L. McCreery, Nano Lett. 2011, 11, 4725-4729.

[4] a) S. Trevin, F. Bedioui, M. Guadalupe Gomez Villegas, C. BiedCharreton, J. Mater. Chem. 1997, 7, 923-928; b) T. Malinski, Z. Taha, Nature 1992, 358, 676-678.

[5] H. H. De Paz, C. Médard, M. Morin, J. Electroanal. Chem. 2010, 648, 163-168.

[6] J. E. Hutchison, T. A. Postlethwaite, C.-h. Chen, K. W. Hathcock, R. S. Ingram, W. Ou, R. W. Linton, R. W. Murray, D. A. Tyvoll, L. L. Chng, J. P. Collman, Langmuir 1997, 13, 2143-2148.

[7] A. Krawicz, J. Palazzo, G.-C. Wang, P. H. Dinolfo, RSC Advances 2012 2, 7513-7522.

[8] S. Ssenyange, F. Anariba, D. F. Bocian, R. L. McCreery, Langmuir 2005, 21, 11105-11112.

[9] A. R. McDonald, N. Franssen, G. P. M. van Klink, G. van Koten, J. Organomet. Chem. 2009, 694, 2153-2162.

[10] M. V. Sheridan, K. Lam, W. E. Geiger, Angew. Chem. Int. Ed. 2013, 52, $12897-12900$
[11] a) J. Rault-Berthelot, C. Paul-Roth, C. Poriel, S. Juillard, S. Ballut, S Drouet, G. Simonneaux, J. Electroanal. Chem. 2008, 623, 204-214; b) C. Poriel, Y. Ferrand, P. le Maux, J. Raul-Berthelot, G. Simonneaux, Chem. Commun. 2003, 1104-1105.

[12] a) A. J. Gross, C. Bucher, L. Coche-Guerente, P. Labbé, A. J. Downard, J.-C. Moutet, Electrochem. Comm. 2011, 13, 1236-1239; b) M. Picot, I. Nicolas, C. Poriel, J. Rault-Berthelot, F. Barrière, Electrochem. Comm. 2012, 20,167-170; c) S. Mahouche-Chergui, S. Gam-Derouich, C. Mangeney, M. M. Chehimi, Chem. Soc. Rev. 2011, 40, 4143-4166.

[13] a) D. Belanger, J. Pinson, Chem. Soc. Rev. 2011, 40, 3995-4048; b) M. Opallo, A. Lesniewski, J. Electroanal. Chem. 2011, 656, 2-16.

[14] S. Hebié, A. K. D. Dimé, C. H. Devillers, D. Lucas, Chem. Eur. J. 2015 21, 8281-8289.

[15] a) S. Baranton, D. Bélanger, J. Phys. Chem. B 2005, 109, 24401-24410; b) A. Benedetto, M. Balog, P. Viel, F. Le Derf, M. Sallé, S. Palacin, Electrochim. Acta 2008, 53, 7117-7122; c) P. A. Brooksby, A. J. Downard, Langmuir 2004, 20, 5038-5045.

[16] A. J. Downard, Langmuir 2000, 16, 9680-9682.

[17] K. M. Kadish, E. V. Caemelbecke, G. Royal, in The Porphyrin Handbook, Vol. 8 (Eds.: K. M. Kadish, K. M. Smith, R. Guilard), Academic Press, 2000, pp. 1-114.

[18] a) S. Cosnier, C. Gondran, R. Wessel, F.-P. Montforts, M. Wedel, J. Electroanal. Chem. 2000, 488, 83-91; b) M. A. Carvalho de Medeiros, S. Cosnier, A. Deronzier, J.-C. Moutet, Inorg. Chem. 1996, 35, 2659-2664 c) M. A. Vorotyntsev, D. V. Konev, C. H. Devillers, I. Bezverkhyy, O. Heintz, Electrochim. Acta 2010, 55, 6703-6714.

[19] S. Gottesfeld, A. Redondo, I. Rubinstein, S. W. Feldberg, J. Electroanal. Chem. 1989, 265, 15-22.

[20] A. K. D. Dimé, C. H. Devillers, H. Cattey, B. Habermeyer, D. Lucas, Dalton Trans. 2012, 41, 929-936.

[21] Y. R. Leroux, P. Hapiot, Chem. Mater. 2013, 25, 489-495.

[22] a) C. Amatore, J. M. Savéant, D. Tessier, J. Electroanal. Chem. 1983, 147, 39-51; b) D. Menshykau, R. G. Compton, Langmuir 2009, 25, 25192529.

[23] C. H. Devillers, S. Hebié, D. Lucas, H. Cattey, S. Clément, S. Richeter, J. Org. Chem. 2014, 79, 6424-6434.

[24] a) A. K. D. Dimé, C. H. Devillers, H. Cattey, D. Lucas, Dalton Trans 2014, 43, 14554-14564; b) D. V. Konev, C. H. Devillers, K. V. Lizgina, T. S. Zyubina, A. S. Zyubin, L. A. Valkova, M. A. Vorotyntsev, Electrochim. Acta 2014, 122, 3-10

[25] a) P. K. B. Palomaki, P. H. Dinolfo, ACS Appl. Mater. Interfaces 2011, 3 4703-4713; b) D.-J. Qian, C. Nakamura, T. Ishida, S.-O. Wenk, T. Wakayama, S. Takeda, J. Miyake, Langmuir 2002, 18, 10237-10242.

[26] C. H. Devillers, A. Milet, J.-C. Moutet, J. Pecaut, G. Royal, E. SaintAman, C. Bucher, Dalton Trans. 2013, 42, 1196-1209.

[27] G. Shul, R. Parent, H. A. Mosqueda, D. Bélanger, ACS Appl. Mater Interfaces 2013, 5, 1468-1473. 


\section{Entry for the Table of Contents}

Layout 2:

\section{COMMUNICATION}

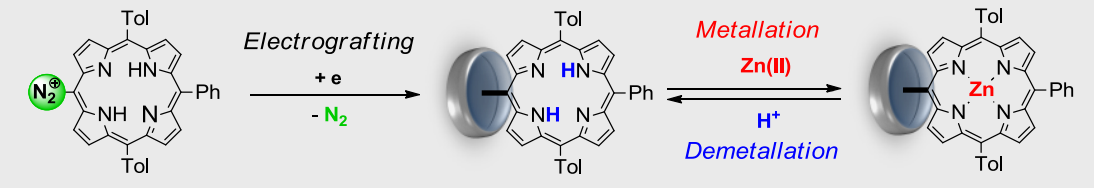

French connection. Electroreduction of free base meso-diazonium-triarylporphyrins leads to the formation of a directly (i.e. without any spacer) and covalently grafted porphyrin film on GC, ITO and Pt electrodes (see picture). This new material is characterized by cyclic voltammetry, UV-Visible absorption spectroscopy and water angle contact. Efficient and reversible zinc metallation of the porphyrin units is also demonstrated.
Seydou Hebié, Charles H. Devillers, * Sophie Fournier and Dominique Lucas*

Page No. - Page No.

Direct grafting of free base mesotriarylporphyrins on GC, ITO and Pt via 5-diazonium-triarylporphyrin electroreduction. Reversible zinc(II)metallation of the resulting materials 